\title{
Information between hybrid interfaces of technical images
}

Quote: OLIVEIRA, Andréia Machado. Information between hybrid interfaces of technical images. Porto Arte: Revista de Artes Visuais. Porto Alegre: PPGAVUFRGS, v. 23, n. 38, p.1-5, jan.jun. 2018. e-ISSN 2179-8001. DOI: http://dx.doi. org/10.22456/2179-8001.80765

\section{Translated by Roberto Cataldo Costa}

Abstract: This article focuses on technical images that pervade our forms of dwelling, feeling, thinking, perceiving and expressing. It aims at reflecting upon today's expressions of the multiple and its hybrid interfaces under two assumptions: first, that production of multiple images implies, directly or indirectly, understanding technical images that result from emerging technological apparatuses; second, that understanding interfaces requires an approach to hybrid interfaces that produce images while constituting themselves as images.

Keywords: Technical images. Multiple. Hybrid interfaces.

We start from the idea that, when image is constituted, it incorporates all the technical and technological processes through which materializes. Expressive actions are repeated as matter-taking-on-form - energies carried through distinct supports/matrices, which may be analog or digital, in a physical space and in the cyberspace, encompassing perceptive, artistic, political, social, affective or existential aspects. That is, these are incarnated images materializing in the experiences of their own constitutions, which are located in the intervals between subjects and objects and which, as Geoffrey Batchen points out, "embody the duration of actions rather than the instant of time" (BATCHEN, 2013, p.48).

In 1968, thinking of image not only as representation or language but also as action, American art critic and curator Eugene Goossen already said that:

the new attitude has turned art inside out: instead of perceptual experiences being accepted as meanings for an end, they have become ends in themselves .... the spectator is not given symbols, but facts to make of them what he can ... what was once concealed within art - the technical devices employed by the artist - is now overtly revealed; and what once was the outside - the meaning of its forms - has been turned inside (GOOSSEN, 1968).

We are surrounded and invaded by images that pervade our forms of dwelling, feeling, thinking, perceiving and expressing. From ephemeral images such as remote shadow play and $19^{\text {th }}$-century phantasmagoria spectacles to penetrating images of printmaking's millennia-old language to photographer Hippolyte Bayard's (1839) studies testing light patterns on chemically sensitive surfaces to today's experiences in digital photography, videomapping, fulldome and 360 projection, luminous graffiti, facade art, among others, we find multiple surfaces that explore distinct ways for presenting, navigating, interacting, recording and reproducing. We are cut through and even invaded by the technical images produced by current technological apparatuses. We are faced with images that constantly want to reproduce themselves and demand their exhibition value, as Walter Benjamin (1994) would put it.

Therefore, in order to think about images as expressions of the multiple and their current hybrid interfaces, we chose to start this article by two assumptions: first, that production of multiple images directly or indirectly implies understanding technical images that result from emerging technological devices; and second, that understanding interfaces requires an approach to hybrid interfaces that produce images while constituting themselves as images. Therefore, we seek a reference in Walter Benjamin with his notion of technical reproducibility, in Vilém Flusser with his idea of technical image and apparatus, and in Gilbert Simondon with his concept of information.

Every expression needs a medium to be realized, the use of a certain technology to be transported, a matter to materialize and give form to thought - something we will now call interface. "Everything that is translation, transformation, passage is of the order of the interface" (LÉVY, 1993, p.181). According to Pierre Lévy,

The ideia of interface can also extend beyond the domain of artifacts. This is, by the way, its vocation, since interface is a surface of contact, of translation, of interconnection between two spaces, two species, two distinct reality orders: from one code to another, from analogue to digital, from mechanic for human (LÉVY, 1993, p.181).

Interfaces are socius-building technologies, they are means by which social assemblages occur. We can say that there is a double construction in the assemblages between technological interfaces and society: interfaces constitute forms of subjectivity while subjects themselves create technologies according to their needs and desires.

We speak of hybrid interfaces because "the result of the hybridization process is not simply a mechanical sum of 
previously existing parts, but a new 'species' - a new kind of visual aesthetics that did not exist previously" (Manovich, 2013, p.259). It is an aesthetics based on the very process of hybridization and reproduction, which is somehow implicit in the creation of multiples.

Incorporating the hybrid and the multiple into their creations from the 1960s on, "as artists expanded their creative visions, printed and editioned formats with their inherent properties of transference, reproduction, sequencing and multiplicity were essential vehicles for enhancing and further articulating their practices" (WYE, WEITMAN, 2006, p.15). Therefore, we can cite Joseph Beuys's multiples - about 600 edited objects ranging from wool suits to innumerable significant empty wooden boxes in his work Intuition (1968). With his multiples, Beuys's found a way to exercise his political activism and spread his social, political, and artistic views on art and life, as he put it: "If you have all my multiples, then you have all of me" - an irony about the idea of totality and unity.

In contemporary times, Antoni Muntadas also uses the power of the multiple in works that are spread in stickers, labels, leaflets, bookmarks and newspaper inserts, resulting - as Beuys - in questions about social, political and economic structures. The series On Translation: Warning (1999-present) features more than 35 projects exhibited in Geneva, Montevideo, Florence, Tokyo, among other cities. Through the very language of the media, Muntadas aims to disturb people regarding messages conveyed in everyday life and socially absorbed. His works are technological and social interfaces that provoke other ways of thinking of the social itself.

It can be said that the power of the multiple and its social and political relationships are implicated in technological means for image reproduction as Walter Benjamin (1994) pointed out. When reflecting upon perception in the age of technical reproducibility, Benjamin saw technological means for art production not as mere apparatuses alien to creation, but as determinants of creation procedures and languages. Technique is operative, it belongs to the realm of scientific knowledge, and it works together with art's aesthetic issues. Being contemporary to the artist, it is brought to the public and placed according to the changes society undergoes in its interaction with current culture (OLIVEIRA; KANNAN; FONSECA, 2015).
Benjamin proposes to break away from unitary reference, from the need for coherence and unity in the work of art, from originality and authenticity in making - that is, the work of art tends to be more circumscribed as a function of reproducibility and less as a function of the original, unique and authentic work. After the emergence of technological means for image reproduction - specifically photography and film - art can no longer be seen as a finished product and measured by its aura. The concept of authenticity escapes technical reproducibility when it loses reference to the original - to that object which is equal and identical to itself. As Benjamin points out, "the here and now of the original underlies the concept of its authenticity, and on the latter in turn is founded the idea of a tradition which has passed the object down as the same, identical thing to the present day" (1994, p.167). Unity and durability give way to transitoriness, repetition and reproduction that brings the work closer to the spectator and replaces its unique existence with a serial one (OLIVEIRA, 2010). The work of art thus created is to be reproduced, so it is increasingly emancipated from its ritualistic role in which the importance used to lie in the fact that images were kept under certain secrecy, with restricted exposure. In reproducibility, based on political praxis, "the work of art reproduced is increasingly the reproduction of a work of art created to be reproduced" (BENJAMIN 1994, p.171). Then the exhibitability of technical images increases since they are produced in order to reach greater visibility. According to Benjamin, "contemporary art will be all the more effective the more it is guided by reproducibility and therefore the less centered it is on the original work" (BENJAMIN 1994, p.180).

Therefore, Spanish artist Jesús Pastor transits through printmaking, photography, sculpture and video, investigating notions of repetition, multiplicity, series, modulation, originality, circulation and appropriation. With an interest in the multiple image, he challenges the notion of print as a category and a disciplinary technical etiquette in favor of a systemic notion of the art of the multiple (BENITO, 2009), "a dynamic structure of non-hierarchical interrelationships and mediations, a system adaptable to the incorporation of new components and permeable to flows, circulations and structural readjustments" (BENITO, 2009, p.18). Having the plan as the dimension of his poetic research, Pastor seeks, "through material realization, direct sensory experience and valorization of 
perceptual qualities" (BENITO, 2009, p.19) in multiple images, as in the overlapping of glasses in Latitudes (2005-2007) or in the series Pensando en Leibniz \#1 (2009) in which he questions what multiplicity, repetition and difference are. Benito states that Pastor undertakes "a critical analysis of printmaking, whether by challenging of mimetic identity in the works of a series, by rejecting copy and the strict reproducibility of the matrix, or - which is the same - by redefining the multiple image as a modular sum of subtle meaningful variations" (BENITO, 2009, p.21).

Pastor's works are surfaces holding repetitions that, when repeated, generate distinction from themselves in technical images. For Vilém Flusser (2002), technical images are transcoding surfaces that need to be decoded considering the apparatus that produced them, since it already includes applied scientific knowledge in it. Thus, the artist "somehow wants to 'deprogram' technique, to distort its symbolic functions, thus forcing them to function outside their familiar parameters and to show their mechanisms for control and seduction" (FLUSSER, 2002, p.22). Flusser notes certain magical behavior that responds to an already given programming, and the artist's challenge is to exhaust its mode of operation: "The man who manipulates is not a worker; he is rather a player: no longer homo faber, but homo ludens. And such a man does not play with his toy, but rather against it" (FLUSSER, 2002, p.24). There are answers already programmed by the apparatus (hardware and software), which deceive us into believing that we have total autonomy. Flusser warns us that "we are already spontaneously thinking computerically, programmatically, in an apparatus-like, imagetical way. We are thinking in the way computers 'think"' (2002, p.73).

American multimedia artist, sculptor and filmmaker Scott Hessels seeks relationships between the moving image and the environment. In the video installation The Moon is a Mirror, ${ }^{1}$ he mixes analog and digital languages. Organic materials in translucent resin are laid on five LED panels with steel frames and converse with a programming resulting in an animation (Figure 1). LEDs give visibility both to moving human image and to translucent organic surfaces that create different ambiences. There is interplay between natural and digital, still and moving images, near and far, recognizable and unrecognizable.

1. Work presented at ISEA Kong-Hong 2016.

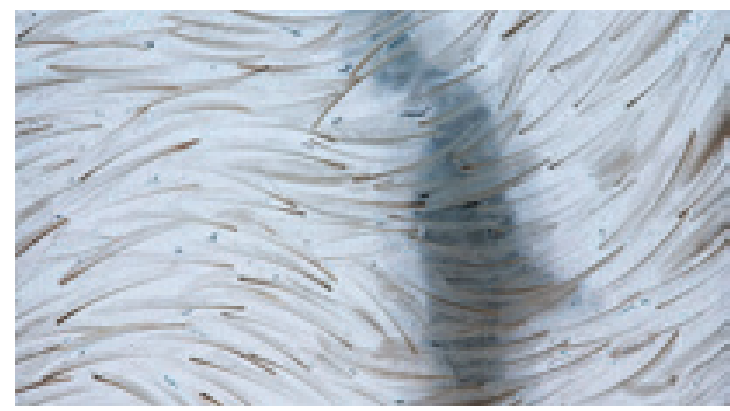

Figure 1. Scott Hessels, The Moon is a Mirror (detail), video instalation, 2016. Source: https://i.vimeocdn.com/video/532859529_1280x720.jpg (Creative Commons).

By placing an ephemeral digital matrix over an analog matrix stratified by the resin, Hessels builds a system of multiple hybrid layers of organic and electronic elements (Figure 1). He resorts to low-cost commercial LED panels originally used for advertising purposes. However, as the artist puts it, they might somehow lead us to the idea of light projection from the early days of cinema. "The title, 'The Moon is a Mirror', reminds us that the moon itself is reflected and displayed light, and that nature has been media in many forms long before we began our journey into creating our own moving image" (Hessels, 2016, p.138).

Furthermore, when passing through analog and digital technologies, Enrique Leal's prints expose the information transmitted by insects that dig into the wood to deposit their larvae (Figure 2). In the series Entomography, with all respect to the aesthetic knowledge produced by these small animals, Leal unveils and reveals the information left in the wood traces by the bark engraving beetles (as Leal calls them). His poetic process points out that "successive interpenetration of reproductive media represents systems capable of producing, projecting and combining images obtained as documents conceived with their own aesthetic statements" (LEAL, 2016, p.169). Starting from an elementary gesture of pressing twigs to make incisions on clay plates, he obtains unique matrices with graphs that are enigmatic to human comprehension. The artist does not appropriate consumer objects - as Andy Warhol does - but objects made by nonhumans, which are full of information. In order to compose a piece of "writing", such inscriptions pass onto photopolymer plates as well as silicone molds. Subsequently, the molds are scanned and digitally printed images are created, giving rise to the series 
Corpúsculos (2015) (Figure 2), where the very larvae that occupied the engraved incisions become visible. The artist also reproduces linen paper replicas that are later digitally photographed and printed, undergoing manual, mechanical and digital processes. For Leal, "the series exhibit intercalated images with the same origin, which participate in different processes, degrees of gestation and self-referential meanings that reveal multiple readings of printing media" (LEAL, 2016, p.117). Each printing process produces specific information, being more than human data open to semantic readings.

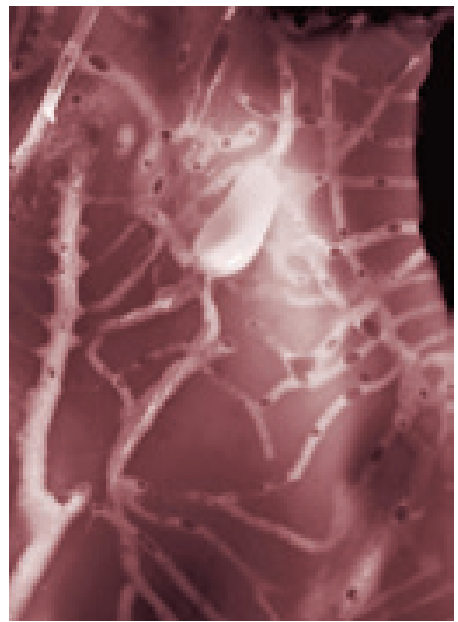

Figure 2. Enrique Leal, Corpúsculos, digitally printed image, 2015

By transporting the information produced by the insects to his prints through various technical and technological processes, Leal brings us closer to French philosopher Gilbert Simondon's concept of information. For Simondon, "information is the beginning of individuation, a requirement of individuation; it is never a given; there is no information unity or identity, since information is not a term" (Simondon, 2003, p.110). Leal's prints are full of information from engraving beetles, but it is not some recognizable, given information; it rather triggers thoughts and perceptions from the individuation processes in which they are involved. The information produced in the work of art is what triggers the movement of individuation of the work itself rather than what we recognize about it. That information has no a priori meaning; it is that which is not yet human, form, individual. It is "the disparity between energy fields" (MASSUMI, 2009, p.43) rather than being frozen as one form. "The in-formation process is a new model of diffusion and contagion that Simondon calls transduction: individuation in a pre-individual, meta-stable plan of disparate virtualities" (TOSCANO, 2007, p.198).

Therefore, information is not a given term, but a process of signification that emerges from a triggering between distinct realities. The information needs a certain margin of indetermination to occur, but it is not pure indetermination, and it also needs regularities and determinations to be communicated. Form is determined, and it might receive the information that is the unpredictability of some variation. Thus, according to Simondon, there is pure indetermination (chance), form, and information. Information can be seen as the trigger that activates implicit forms of matter, maintaining the very dynamics of those forms. Technical images are produced in this process of form and information, i. e., that which is determined by the equipment and the possible indetermination mediated by the human. "The machines that can receive information are those that localize its indetermination" (SIMONDON, 1989, p.158), that is, at one moment, we need to understand the equipment's workings and, on another, to open its indeterminations in order to produce difference and creation. "In the course of this passage from potential to present, information intervenes; information is a condition for updating" (SIMONDON, 1989, p.160). Thus, information transits between the virtualities of the matters and the updates of the forms.

Therefore, the information produced by Beuys, Muntadas, Pastor, Hessels and Leal are disparities arising from different realities captured by intuition, aesthetically expressed as mattertaking-on-form and materialized by certain techniques and technologies that, in turn, also produce information from their indeterminations. The pieces of information that dwell in the works of these artists are not representations of something known or data to be identified by recognition; on the contrary, they are disturbances that disrupt established structures, explore technological indeterminations, extract techno-aesthetic qualitative expressions, and cause opening to processes of contagion.

I raise these issues in an attempt to contribute to the debate on the Expressions of the Multiple, thinking of the multiple as repetitions that differ by repeating themselves, as Gilles Deleuze (1988) argues in Difference and Repetition which distinguish themselves when they move through different technological media and which, in each repetition, produce information expressing difference. 


\section{REFERENCES}

BATCHEN, Geoffrey. "Photography", an art of the real. In: SQUIERS, Carol (Org.) What is a Photograph? New York: International Center of Photography, 2013.

BENITO, Blas Javier. Pensar problematicamente. Teoría de la imagen en Jesús Pastor. In: Estampa 09. $17^{\circ}$ Feria internacional de Arte Múltiple Contemporáneo. Madrid, 2009.

BENJAMIN, Walter. Magia e técnica, arte e política: ensaios sobre literatura e história da cultura. São Paulo: Brasiliense, 1994.

DELEUZE, Gilles. Diferença e Repetição. Rio de Janeiro: Graal, 1988.

FLUSSER, Vilém. Filosofia da caixa preta: ensaios para uma futura filosofia da fotografia. Rio de Janeiro: Relume Dumará, 2002.

GOOSSEN, E. C. The Art of the Real. Museum of Modern Art, New York, July 3, 1968.

HESSELS, Scott. The Moon is a Mirror. In: ISEA 2016 Hong Kong - Cultural Revolution. Hong Kong: School of Creative Media, 2016.

LEAL, Enrique. A poética do resgate. Encontrar pegadas, criar impressões. In: KANNAN, Helena (Ed.). Rhinocerus: gravura, palavra, imaginário. Porto Alegre: Libretos, 2016.

LÉVY, Pierre. As tecnologias da inteligência. Rio de Janeiro: Ed. 34, 1993.

MANOVICH, Lev. Software takes command. Nova York: Bloomsbury, 2013.

MASSUMI, Brian. "Technical Alimental” revisited: Brian Massumi on Gilbert Simondon. In: Parrhesia, n. 7, 2009, p.36-45.

OLIVEIRA, Andréia Machado. Corpos Associados: Interatividade e Tecnicidade nas Paisagens da Arte. PhD Thesis in Artand Technology. UFRGS, Porto Alegre, December 2010.

OLIVEIRA, Andréia Machado; KANNAN, Helena A. R; FONSECA, Tânia Mara G. A gravura como objeto tecno-estético. In: Revista Educação Gráfica, v. 1, p.181-195, 2015.

SIMONDON, Gilbert. Du mode d'existence des objects techniques. Paris: Editions Aubier, 1989.

TOSCANO, Alberto. Technical Culture and the Limits of the Interaction. In: BROUWER, Joke \& MULDER, Arjen. Interact or Die! Rotterdam: NAi Publishers, 2007, p.198-205.

WYE, Deborah e WEITMAN, Wendy. Eye on Europe: prints, books and multiples from 1960 to now. New York: MOMA, 2006.

Andréia Machado Oliveira: is a multimedia artist; she received a PhD in Computers in Education from UFRGS (Brazil) and Université de Montréal (Canada). She conceived and coordinates UFSM's LabInter (Interdisciplinary Interactivity Lab) and has headed the research group gpc.InterArtec/Cnpq since 2012. She is a professor at the Department of Visual Arts of the Graduate Studies Program in Visual Arts and the Graduate Studies Program in Networked Educational Technology at UFSM.

(*)Article sent in July 2017 